\title{
"Sounds that Create the Image." On Polish and Russian Translations of Alliteration in Pnin by Vladimir Nabokov
}

\author{
Olga Letka-Spychala \\ University of Warmia and Mazury, Poland \\ olga.letka@uwm.edu.pll
}

\begin{abstract}
The article explores procedures used for the rendition of alliteration in the novel Pnin written by Vladimir Nabokov (1957). Two target texts will be compared. The first one is the Polish translation prepared by Anna Kolyszko (1987), the second one is the Russian version done by Sergey Ilyin (1993). The analysis of the texts will draw on research into three major thematic areas: proper names, appearance and feelings/emotions where an accumulation of alliteration is distinctly noticeable. These fields are linked by the focal character, a Russian émigré who comes to America after the Russian Revolution. His oddness and eccentricity are constantly emphasized by the unreliable narrator, whose speech abounds in alliterations. In the original this device not only reinforces the narrator's orality but also structures the image of the focal character. In the target texts alliteration is subject to various formal modifications. In many cases it is substituted by onomatopoeias, consonances, descriptive equivalents or it is simply abandoned. As a result, the translators do not always preserve the alliterative effect (especially when it comes to proper names, feelings and emotions). Translation procedures applied by the translators allow them to achieve partial equivalence on the semantic level. Inaccuracies in this field are visible in examples referring to Pnin's feelings and emotions in which alliterative word strings are omitted and semantically distant counterparts are used.
\end{abstract}

Keywords: Vladimir Nabokov, Pnin, alliteration, translation procedures, Polish language, Russian language, character's image, sound

\section{Streszczenie}

„Dźwięki, które tworzą obraz”. O przekładzie aliteracji w polskiej i rosyjskiej wersji Pnina Vladimira Nabokova

Celem niniejszego artykułu jest analiza $i$ porównanie rozwiązań translatorskich zastosowanych $w$ przektadzie aliteracji. Materiat badawczy został zaczerpnięty z utworu Pnin (1957) Vladimira Nabokova, jego polskojęzycznej wersji przettumaczonej przez Annę Kołyszko (1987) roku oraz rosyjskojęzycznego wariantu przygotowanego przez Siergieja Iljina (1993). Nagromadzenie aliteracji jest widoczne $w$ trzech grupach tematycznych. Pierwsza stanowia nazwy własne, następnie wygląd zewnętrzny, uczucia oraz emocje. Wymienione grupy 
tematyczne odnosza się do postaci głównego bohatera Timofieja Pnina - rosyjskiego emigranta mieszkającego w Ameryce. Oprócz niego niezwykle ważna postacia w utworze jest „, nierzetelny" narrator, który w swych opisach , kreuje” ekscentryczny i nieco dziwaczny obraz głównego bohatera. W oryginale to właśnie dzięki aliteracjom zarówno jego wypowiedzi, jak również sam Pnin nabieraja charakterystycznego ,humorystycznego" zabarwienia. W przekładach nie zawsze ten efekt zostaje osiagnięty bowiem aliteracje ulegaja formalnym modyfikacjom i sa zastapione przez onomatopeje, konsonse, ekwiwalenty opisowe (szczególnie dotyczy to wygladu zewnętrznego) bądź zostaja calkowicie utracone (w grupie obejmujacej imiona własne oraz uczucia i emocje). Zastosowane zabiegi translatorskie doprowadzity do zmiany lub utraty oryginalnej, fonetycznej wartości. Umożliwity również osiagnięcie częściowej ekwiwalencji na poziomie semantycznym. Istotne rozbieżności na tej płaszczyźnie sa widoczne w przyktadach opisujacych emocje Pnina, w których tlumacze nie tylko nie oddali aliteracji, ale również wykorzystali odległe semantycznie odpowiedniki.

Stowa kluczowe: Vladimir Nabokov, Pnin, aliteracje, metody translatorskie, język polski, język rosyjski, obraz bohatera, dźwięk

\section{Introduction}

In a narrow sense alliteration is considered as a repetition of consonants with further differentiation depending on whether the repetition "has a purely euphonic or metrical role" (Lotman, Lotman 2015: 34). In a wider sense this figure of speech is viewed as a part of instrumentation in which, as a result of the close proximity of certain sounds, both phonetic and semantic subtleties of literary works are retrieved (Lotman, Lotman 2015: 34). This device may perform various functions among which the most evident is the aesthetic one. Texts gain additional musical and phonetic values and, by inducing sensory impressions, immediately attract attention. Consequently, in this respect a memorative aspect of alliteration is emphasized since repetitive sounds are etched into the readers' memory (cf. Lea et al. 2008).

A verse creating function (related to high-order units formed within the text by parts of verses or verses themselves) in Old English poetry is discussed in works written by Richard A. Lewis (1973), David L. Hoover (1985), David Cronan (1986), Jun Terasawa (2011) and Jonathan Roper (2012). The last scholar, following Cronan's example, develops the concept of alliterative rank - "the measure of how frequently a particular word appears, usually expressed as a percentage" (Roper 2012: 87). He comes to a conclusion that sound repetitions to some extent limit poets' choices of words and "restrict making of sense in English language" (Roper 2012: 88). In order to achieve an acoustic effect authors use synonyms, which leads to haze of alliterative verse defined by Mari Sarv as "obscuring, changing and extending of the conventional denotation of words when they are placed in alliterative combinations." (Sarv 
1999: 127; see also Roper 2012). Alliteration as a constituent principle is also examined by James I. Wimsatt (1998), who explores sound repetitions in Gerard Monley Hopkin's sprung rhythm, and Ulrich K. Goldsmith (1950) analysing the structure of Shakespeare's sonnets. A function of this poetic device which is not less important is the semantic one, which refers to creating an affinity between words with similar sounds. In this context alliteration serves as a special type of paronomasia (Kujawska-Lis 2018: 90).

It must be stressed that alliteration does not have to be related mainly to literary texts. There are studies which examine its presence and main function in English names of places (Harte 2015), Anglophone idioms, proverbs (Williams 2015) or inaugural addresses of presidents of the United States (Halmari 2015). Karen Smith (2006) analyses rhetorical devices in advertising headlines and their translation into Russian. ${ }^{1}$ Roper (2014) enumerates microgenres (proverbs, sayings, titles of books, nicknames) which are more alliterative than others. Similar observations concern languages with the initial syllable stress in which the frequency of alliteration is very high (Roper 2014: 422).

Alliteration has a long tradition in English literature: suffice it to mention Beowulf, the Old English epic poem or the $14^{\text {th }}$ century chivalric romance Sir Gawain and the Green Knight distinguished by an alliterative verse organizing the metrical structure of these works. In Russia alliteration was used by Pushkin ( $19^{\text {th }}$ century) but became particularly popular in the Silver Age, a period in art referring to the end of the $19^{\text {th }}$ century and the beginning of the $20^{\text {th }}$ century. Turbulent political events, social and cultural changes, and industrialization had an impact on the appearance of new tendencies in literature. In contrast to the Golden Age of Russian prose, it was the epoch of the dominance of poetry. At that time many art movements and literary currents emerged, for instance Symbolism, Acmeism and Futurism. Their prominent representatives used totally different means to express themselves. Symbolists were fond of complex metaphors and misleading allusions, and strove to show the beauty of the text, Acmeists preferred simplicity and rationality. Against this background, the group of Futurists seemed to be remarkably colourful. Their main aim was to restructure the language of poetry. As grammatical and syntactic systems limited artistic freedom, poets rejected the regular system of versification, orthography and punctuation. They invented new words to convey new meanings and created a theory of "abstruse language" (заумный язык), understandable only on the basis of etymological and sound associations. A poetic text was treated as a chaotic and

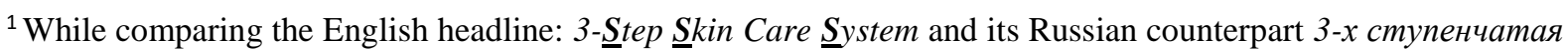
программа ухода за кожей, Smith concludes that alliteration is a non-translated figure and its substitution with another trope is not as effective as in the original (Smith 2006: 165).
} 
illogical combination of crossing and overlapping sounds. In order to achieve the effect of disharmony, poets mixed diverse phonic devices (alliteration, consonance, assonance) (Mucha 2002: 350). The example below indicates how one of them - alliteration - functions and shapes the acoustic layer of the poem:

\begin{tabular}{|c|c|}
\hline $\begin{array}{c}\text { Хорошее отношение к лошадям } \\
\text { Владимир Маяковский }\end{array}$ & $\begin{array}{l}\text { The Good Treatment for Horses } \\
\text { (translator: Tamara Vardomskaya) }\end{array}$ \\
\hline Били копыта, & The hoofs came tripping, \\
\hline Пели будто: & Sang to the cobbles: \\
\hline - Гриб. & $\underline{\text { Climp }}$ \\
\hline Грабь. & $\underline{\text { Clomp }}$ \\
\hline Гроб. & $\underline{\text { Clamp }}$ \\
\hline$\overline{\mathbf{\Gamma}}$ руб. & Élump. \\
\hline
\end{tabular}

When comparing these passages, one can argue that alliteration is difficult to tackle especially in terms of their translation. As Lotman and Lotman (2015: 34) state, not only differences between languages and physical properties of phonetic entities but also certain poetry traditions may interfere with its faithful recreation. Unlike the English poetic system, in the Russian folk tradition there is no alliterative verse, instead there are other phonetic tropes such as paronymy or episodic rhyme (Lotman, Lotman 2015: 39). The next difficulty lies in the fact that even if alliteration is introduced in the target text [henceforth: TT], it may convey different concepts and evoke different associations. This can be illustrated with the phenomenon called by Roper semantic stretch when shifts in sense occur (Roper 2014: 421). Thirdly, the "existence" of alliteration in the TT fully depends on translators' competences and creativity in seeking means which preserve the auditory and semantic content of the original.

\section{Methodology}

In this article I explore translation procedures applied in the novel Pnin written by Vladimir Nabokov. Two target texts will be compared. The first one is the Polish translation prepared by Anna Kołyszko in 1987, the second one is the Russian version done by Sergey Ilyin in 1993. ${ }^{4}$ My analysis of the texts draws on research into three major thematic areas: proper

\footnotetext{
${ }^{2}$ Examples are taken from the website: http://www.stihi-rus.ru/1/Mayakovskiy/54.htm, Accessed 28 Feb 2019.

${ }^{3}$ Examples are taken from the website: https://vardomskaya.com/2016/07/26/the-good-treatment-of-horses-vmayakovsky/, Accessed 28 Feb 2019.

4 The first translation of Pnin which appeared in Russia was done by Gennady Barabtarlo (1949-2019) in 1989. He was a Professor of Russian at the University of Missouri and authored numerous articles devoted to Nabokov's output. The translator also belonged to the international society The Nabokovian founded in 1978 by Stephen Jan Parker. He edited the section "The Notes and Brief Annotations" (Blackwell: online). What is interesting,
} 
names, appearance and feelings/emotions where an accumulation of alliteration is distinctly noticeable. Within this analysis I suggest that these fields are linked by the focal character Timofey Pnin, a Russian émigré who comes to America after the Russian Revolution. His oddness and eccentricity are constantly exaggerated by the unreliable narrator, whose speech abounds in alliterations. In the original this device not only reinforces the narrator's orality but also structures the image of the character. I propose that formal modifications, which alliteration is subject to in the target texts, may affect the way translators present Pnin to the target audience.

\section{Pnin - characteristics of the source text $t^{5}$}

Pnin - the writer's $13^{\text {th }}$ novel was published in 1957 by Doubleday. Initially Nabokov released separate parts in The New Yorker. The first attempt to publish the novel with the Viking Press was unsuccessful because the editor noticed important inadvertences connected with the fragmentariness of its composition. Probably Nabokov's first intention, expressed in a letter to Edmund Wilson, to "start a series of stories about a creature, a Professor Pnin" (Barabtarlo: online) had influenced the final arrangement of the novel. Nevertheless, Nabokov later revised his plans and stated that it "certainly is not a collection of sketches" (Barabtarlo: online).

Gennady Barabtarlo came to a similar conclusion as regards the structure of the novel and characterized it as "a string of more or less detachable story-length episodes, never really congealing into a novel" (Barabtarlo: online). In other words, Barabtarlo underlines not only the inconsistency in the formal aspect, but also indicates indirectly the application of a special narrative mode. In spite of the expressed reservations, Pnin was appreciated both by readers and critics.

The novel is organized essentially into seven chapters integrated by the main character - a Russian expatriate, Timofey Pavlovich Pnin, who comes to America after the Russian Revolution. Nabokov portrays the drama of a human being forced to abandon his motherland. Dabney Stuart states that Pnin is compelled to keep his past alive through the "reoccurrence of moments of remembering" and calls him a constant reminder of his exiled status (1977: 75). Admittedly, culture clash intensifies his isolation, yet the main character does not wallow in

Barabtarlo translated Nabokov's novels in collaboration with the author's wife, Vera. Apart from Pnin, he also translated The Real Life of Sebastian Knight (2008) and The Original of Laura (2009). The second translation of Pnin was created by a writer and journalist Boris Nosik (1931-2015) in 1991. The last version belongs to Sergey Ilyin (1945-2017).

${ }^{5}$ Henceforth: ST. 
self pity but tries to adapt to the new conditions, and this becomes a source of humorous scenes. For instance, the most "dangerous area" for Pnin was the English language, which is manifested by numerous idiomatic and phraseological transformations, occasional neologisms, semantic shifts and puns being intentionally wrong translations from Russian into English.

Apart from Pnin, the omniscient narrator should be also taken into consideration. This character is enigmatic and ambiguous. He reports on Pnin's Russian émigré life, his work at Waindell College, his relationships with co-workers and students. Much attention is devoted to comments on the protagonist's retrospective memories and it seems that he even sympathizes with his alienation in America. However, his concern for the focal character is illusory because he constantly tries to perpetuate a clumsy and pathetic image of Pnin. He mistreats him, points out his errors and sneers at his external appearance. The narrator is so convincing that his reliability seems incontestable. Even the readers discern the character's awkwardness and start to mock him. However, in Chapter 7 the narrator's veracity is called into question because it comes to light that he is the protagonist's professional and love rival (he was involved in a romance with Liza who tries to commit suicide). Interestingly enough, Pnin only once rebels against him and reveals his deceits:

Now, don't believe a word he says, Georgiy Aramovich. He makes up everything. He once invented that we were schoolmates in Russia and cribbed at examinations. He is a dreadful inventor (on uzhasnïy vïdumshchik) (Nabokov 1957: 54).

Gradually it becomes clear that the whole story about Pnin is only a game. Nabokov shapes the narration on the auditory level and introduces alliterative sequences. Thus the effects of repetition and the phonetic resemblance of certain words are achieved. Despite the fact that formal and etymological correspondence is illusory, it still enhances the storytelling. Nabokov's specific attitude towards words is commented on by Bodenstein as follows:

Words are to him living organisms with magic etymological, morphological, and phonological histories and exciting properties of lexical, associative, and expressive meaning. He accordingly handles them with exceptional deliberation, like a jeweler handles gems. With expertise he examines their qualities of shape, quality, color and brilliance and sets about the task of bringing out their full potentialities (Bodenstein 1977: 56).

In short, Bodenstein highlights the remarkable "creativeness of words" resulting in the evocation of various associations. As he states, in penetrating their senses Nabokov takes into consideration their derivation, and visual and auditory values. Hence, he skillfully places close 
together "semantically distant" lexemes and concepts preserving "a harmony and equivalence on the level of phonology and rhythm" (Bodenstein 1977: 101). It is noticeable that such similarities do not always concern their meanings. Thus, the juxtaposition of words with divergent senses generates a specific tension whose degree varies depending on whether the units are synonymous (slight tension) or antonymous (strongest tension). The same mechanism is applied in creating alliterative chains structurally divided into:

- simple sound patterns - when initial sounds in two words are identical,

- complex sound patterns - when three or more words have a repetitive sound and

- doublets - alliterative pairs combined by words such as "and" or "or" (Lokrantz 1973: 97).

In the following section I will briefly explore methods used in the rendition of alliteration patterns.

\section{Alliteration and its translation}

Unfortunately, little has been written about reconstructing alliteration in literary texts. ${ }^{6}$ As Ewa Kujawska-Lis (2007: 67) points out, scholars' interests oscillate between culture-bound elements, vernaculars, idioms, proper names, metaphors and strategies providing an equivalent and relevant message in the target text, leaving this domain unexplored. As the example of the Futurists' poetry in (1) indicates, alliteration deserves special attention particularly if it plays the role of a semantic dominant - a paramount element essential for the understanding of the senses of poems (Barańczak 2004: 19). Until now, there have been no systematized classifications of procedures used for the translation of alliteration in general. Kujawska-Lis's outlook follows from her analysis of three Polish translations of G. K. Chesterton's short story "The strange crime of John Boulnois" and attempts to deal with this issue. Generally, the ideal situation is when the alliteration in the ST is repeated in the TT. Sometimes this may be achieved by a literal translation although as she states: "in most cases alliteration happens to be inadvertent" (Kujawska-Lis 2007: 72). Among other methods allowing translators to retain the sound effect she also enumerates a substitution which takes various forms:

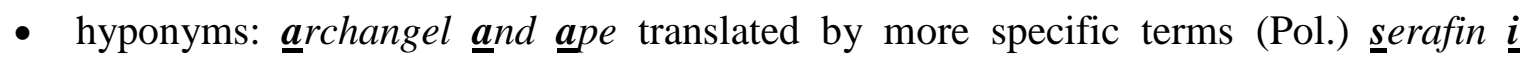
szympans ('seraph and chimpanzee'). As opposed to the examples below, here we are

\footnotetext{
${ }^{6}$ Sample works include, for example: Roper (2014); Lotman, Lotman (2015); Kujawska-Lis (2007).
} 
dealing with approximate alliteration as the words begin with slightly different sounds, $<\mathrm{s}>(/ \mathrm{s} /)$ and $<\mathrm{sz}>(/ \mathrm{S} /)$.

- hypernyms: $\underline{\boldsymbol{d}}$ rowsy $\underline{\boldsymbol{d}}$ og rendered by words with broader meanings as (Pol.) zaspane zwierze ('drowsy animal'),

- $\quad$ synonyms: pragmatists and pugilists represented by lexemes with a near meaning (Pol.) pragmatyści i pięściarze ('pragmatists and boxers'),

- metonymy: freckled face decoded as (Pol.) piegowate policzki ('freckled cheeks'); the phrase in the target language [henceforth: TL] is linked to the original one,

- proper name (anthroponym): $\underline{\boldsymbol{a}}$ rchangel $\underline{\boldsymbol{a}}$ nd $\underline{\boldsymbol{a}}$ pe substituted by (Pol.) $\underline{\boldsymbol{G}}$ abriel i goryl ('Gabriel and gorilla'),

- semantic equivalent: feel like a damned fool translated as (Pol.) czuć się jak ostatni osiot (Kujawska-Lis 2007: 78).

Amplification is another way to overcome phonetic obstacles. It is acceptable when adding a new element does not change the sense of the utterances but provides them with acoustic values. Here, a synonym or another component being absent in the original fragment may occur. Kujawska-Lis lists also compensation - introducing alliteration in a place in which it does not appear in the ST as a method of translating alliteration, whereas omission is not considered as one of them (Kujawska-Lis 2007: 78). This brief review of translating procedures will be the starting point for the comparative analysis of Russian and Polish versions of Nabokov's masterpiece.

\section{Translation of proper names containing alliteration}

In Pnin alliteration occurs in the following configurations:

1. adjective + proper name (surname)

2. common noun + proper name (surname)

Alliterative patterns are established by a voiceless plosive consonant /p/ in the beginning of words. In translations they are de-composed because the "repetitive" effect is weakened by introducing the voiced bilabial stop /b/ and voiceless bilabial stop /p/ as is shown in Table 1: 
Table 1. Onomastics + alliteration

\begin{tabular}{|c|c|c|c|c|c|}
\hline & & \multicolumn{3}{|c|}{ SIMPLE SOUND PATTERNS } & \multirow[b]{2}{*}{ Procedures } \\
\hline No & ST (1957) & TT in Polish (1993) & Procedures & TT in Russian (2012) & \\
\hline $\mathrm{a}$ & $\begin{array}{l}\text { Poor Pnin landed } \\
\text { in the middle of a } \\
\text { strange town (18). }\end{array}$ & $\begin{array}{l}\text { Biedny Pnin znalazł się } \\
\text { w obcym mieście (19). }\end{array}$ & $\begin{array}{l}\text { ALLIT. } \\
\Rightarrow \text { NON- } \\
\text { ALLIT. }\end{array}$ & $\begin{array}{lr}\text { Бедный } & \text { Пнин } \\
\text { высадился } & \text { посреди } \\
\text { чужого города }(22) .\end{array}$ & $\begin{array}{l}\text { ALLIT. } \\
\Rightarrow \text { NON- } \\
\text { ALLIT. }\end{array}$ \\
\hline $\mathrm{b}$ & $\begin{array}{l}\text { Poor Pnin had } \\
\text { come down the } \\
\text { last steps on his } \\
\text { back (99). }\end{array}$ & $\begin{array}{l}\text { Biedny } \underline{\text { Pnin zjechał z }} \\
\text { ostatnich stopni na } \\
\text { plecach (95). }\end{array}$ & $\begin{array}{l}\text { ALLIT. } \\
\Rightarrow \text { NON- } \\
\text { ALLIT. }\end{array}$ & $\begin{array}{l}\text { Бедный } \\
\text { проехался } \text { Ппиной по } \\
\text { последним ступенькам } \\
\text { (99). }\end{array}$ & $\begin{array}{l}\text { ALLIT. } \\
\Rightarrow \text { NON- } \\
\text { ALLIT. }\end{array}$ \\
\hline $\mathrm{c}$ & $\begin{array}{l}\text { my poor Pnin, } \\
\text { with hallucinatory } \\
\text { sharpness, } \\
\text { imagined Mira } \\
\text { slipping out of } \\
\text { there into the } \\
\text { garden and } \\
\text { coming toward } \\
\text { him... (120). }\end{array}$ & $\begin{array}{l}\text { Mój biedny } \underline{\text { Pnin }} \\
\text { widział ze złudną } \\
\text { wyrazistością, jak Mira } \\
\text { wymyka się stamtąd do } \\
\text { ogrodu i do niego (123). }\end{array}$ & $\begin{array}{l}\text { ALLIT. } \\
\Rightarrow \text { NON- } \\
\text { ALLIT. }\end{array}$ & $\begin{array}{l}\text { мой бедный Пнин с } \\
\text { галлюцинаторной } \\
\text { отчетливостью увидел } \\
\text { Миру, с веранды } \\
\text { скользнувшую в } \\
\text { сад и шедшую к } \\
\text { нему... (56). }\end{array}$ & $\begin{array}{l}\text { ALLIT. } \\
\Rightarrow \text { NON- } \\
\text { ALLIT. }\end{array}$ \\
\hline $\mathrm{d}$ & $\begin{array}{l}\text { Lilacs - those } \\
\text { Russian garden } \\
\text { graces, to whose } \\
\text { spring-time } \\
\text { splendour, all } \\
\text { honey and hum, } \\
\text { my poor Pnin } \\
\text { greatly looked } \\
\text { forward...(132). }\end{array}$ & 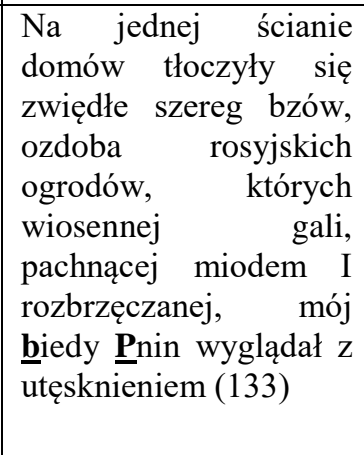 & $\begin{array}{l}\text { ALLIT. } \\
\Rightarrow \text { NON- } \\
\text { ALLIT. }\end{array}$ & $\begin{array}{l}\text { Сирень - } \\
\text { русских садов, }- \text { чье } \\
\text { весеннее } \\
\text { великолепие, в меду и } \\
\text { гудении, } \\
\text { нетерпеньем } \\
\text { предвкушал } \\
\text { бедный друг, } \\
\text { безжизненно } \\
\text { теснилась вдоль одной } \\
\text { из стен дома (133). }\end{array}$ & $\begin{array}{l}\text { ALLIT. } \\
\Rightarrow \text { NON- } \\
\text { ALLIT. }\end{array}$ \\
\hline $\mathrm{e}$ & $\begin{array}{l}\text { I am afraid - } \\
\text { Professor } \quad \text { Pun- } \\
\text { neen (7). }\end{array}$ & Profesora $\underline{\text { Pun-ina (8). }}$ & $\begin{array}{c}\text { ALLIT. } \\
\Rightarrow \text { ALLIT. }\end{array}$ & профессор Пуннин (8). & $\begin{array}{l}\text { ALLIT. } \\
\Rightarrow \text { ALLIT. }\end{array}$ \\
\hline $\mathrm{f}$ & $\begin{array}{l}\text { (Oh, punster } \\
\text { Pnin!) (78). }\end{array}$ & $\begin{array}{l}\text { Ach ten } \underline{\text { kalamburzysta }} \\
\text { Pnin! }(81) .\end{array}$ & $\begin{array}{l}\text { ALLIT. } \\
\Rightarrow \text { NON- } \\
\text { ALLIT. }\end{array}$ & $\begin{array}{l}\text { О м ногосмысленный } \\
\text { П нин! (80). }\end{array}$ & $\begin{array}{l}\text { ALLIT. } \\
\Rightarrow \text { NON- } \\
\text { ALLIT. }\end{array}$ \\
\hline
\end{tabular}

In Nabokov's book there are certain epithets which function as fixed expressions. The phrase poor Pnin is attributed with such a property. This phrase appears in various contexts and situations ranging between tragic and comical. For instance, a humorous effect is achieved when Pnin is invited to deliver a very important lecture in Cremona (1a). Unfortunately, because of his absent-mindedness and an out of date timetable he misses the train and arrives in Whitchurch. A similar result is evident in Pnin's fall down the stairs in his son's presence (1d). But this expression also occurs in scenes dominated by nostalgia and melancholy rather than laughter (1b and 1c). This is evident in the character's recollections of his pre-émigré life in Russia. He mentions his first love, Mira Belochkin, who has been killed and lilac gardens 
whose characteristic sweet smell strongly affects his senses and engraves itself on his memory. Here poor fulfills two functions: semantic, as it "enriches" the main character with new traits and expressive since it reveals the narrator's commiseration towards him.

Furthermore, the lexeme poor has another meaning. Apart from, as already discussed "deserving sympathy", The Cambridge Online Dictionary lists it as "having little money and/or few possessions". In the context of Pnin's traumatic émigré experience and his incessant need to be accepted by the American community, the latter definition acquires a symbolic significance and may be deciphered in a broader sense as the loss of origins and cultural and social values. Anyway, even the main character's surname directly alludes to the character's "lost identity". The sound resemblance with the Russian word пень ('a stump'), a part of the tree that is left after most of it has been removed, is visible. The hewn tree, in a metaphorical way, perfectly depicts Pnin's mental state after leaving his motherland. The surname may be also interpreted as an "anagramical" version of the pain accompanying Pnin throughout the whole book and displayed in the mysterious seizures resembling heart attacks. With regard to the translation of the adjective poor, both Kołyszko and Ilyin are consistent. They do not hesitate to choose the dictionary equivalents biedny in Polish and бедньй in Russian respectively, and transfer the proper name that results in changing the quality of the initial sound: in the original /p/ (voiceless bilabial stop) $+/ \mathrm{p} /$ (voiceless bilabial stop); in the translations /b/ (voiced bilabial stop) + /p/ (voiceless bilabial stop). Naturally, this shift does not introduce any serious changes in the plot but by "amplifying" the plosive consonant $/ \mathrm{b} /$, which in all probability is caused by an inability to find an adequate equivalent, they disrupt the "alliterative flow".

A partial consistency may be observed with respect to rendering the fictional name. This is visible in the Russian text (1d) where the onomastic element is replaced with a more casual form друг (friend). In this way Ilyin intends to signal that the character is intimate with the narrator, who later will appear to be his foe. Such a shift may be viewed as an unnecessary hint from the translator, who divulges Nabokov's secret before the culminating moment in Chapter 7.

It must be stressed that in retaining alliteration the translators are obliged to search for suitable counterparts that both convey the meaning of the original expressions and keep their aesthetic function. Even though Polish and Russian languages have at their disposal words such as poczciwy ('good-natured') Pnin and победная головушка Пнин ('unhappy man'), they belong to different semantic fields and stress totally different aspects of Pnin's personality. Perhaps an objection to using such distant counterparts may have been dictated by the 
translators' fear of being accused of too far-reaching an interference in the character's portrayal.

It is worth mentioning that very often Nabokov creates occasionalisms based on certain names such as "Pninian craving", "Pninian quandary", "Pninizing his new quarters". Furthermore, the author provides his hero's speech with mispronunciations being not simply slips of the tongue but structures containing a double meaning. Usually they concern Pnin's speech yet one exception may be noted. When Judith Clyde, the vice-president of the Cremona Women's Club introduces Pnin to the audience at a lecture she deforms his surname. In the original this lexical lapse is marked graphically as Pun-nin. What is striking about this onomastic element is that it contains a pun in itself. By means of allusion to his favourite literary device, Nabokov marks his presence directly. At the same time, readers are left in suspense whether the figure of Pnin and his pain are genuine or bogus. Therefore, it opens new possibilities for interpretations of the character whose surname, in contrast to previous elucidations, comprises playfulness and creativity.

Unfortunately, translations erase the "double effect" and do not allow recipients to participate in Nabokov's game. Pun-neen is transcribed into Polish with a minor graphic change (Pun-in) and transliterated in the Russian version (Пуннин) without reproducing supplementary information. These solutions demonstrate that the translators, in the case of this proper name, opt for leaving it in an unchanged form, which impoverishes the original. This is also noticeable in the rendition of other proper names, for instance Betty Bliss (Betty Bliss, Бетти Блисс), President Poor (Rektor Poore, Президент Пур) or Head, Dr Hagen (dziekan, doctor Hagen; $\partial-р$ Гаген).

As previously mentioned, in Nabokov's book two contradictory presentations of the main character emerge. Poor Pnin clashes from the beginning of the book with the playful one, called ironically by the narrator a punster - a person fond of making puns (1f). A noticeable distinction between his two images is connected with the motif of mirrors and doppelgangers exploited by Nabokov in many of his works (The Eye, Lolita). In Pnin this theme is developed in Chapter 6 where the narrator states:

Pnin and I had long since accepted the disturbing but seldom discussed fact that on any given college staff one could find not only a person who was uncommonly like one's dentist or the local postmaster, but also a person who had a twin within the same professional group... (Nabokov 1957: 140). 
Pnin discerns such a double in the figure of Professor Thomas Wynn, the Head of the Ornithology Department. Repeatedly he ponders over whether he is meeting the "original" Professor or only a "Wynn-like stranger". This alleged ability of "being multiplied" is demonstrated with the help of wordplay based on blending the initial letter of his name and surname. Pnin with "a bright foreigner's fondness for puns" renames the professor as Twyyn and pronounces it identically as twin (one of two children or animals born at the same birth). In this case "word-de-formation" is not a result of a poor command of English but is created intentionally and testifies to Pnin's great inventiveness. However, there are situations which indicate that his errors are not deliberate and then Pnin is exposed to the narrator's acerbity. His ironic attitude is visible when the main character invites Professor Wynn to a housewarming party and asks about his marital status: "Bring also your spouse - or perhaps

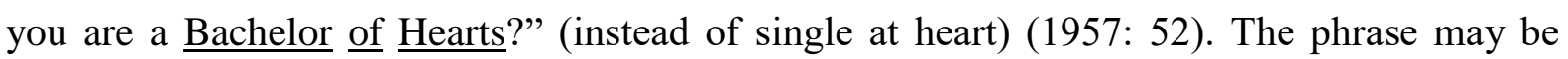
interpreted in two ways: as a faulty use of the idiom "single at heart" or it may be derived from the adjective "single-hearted" which signifies having an honest heart; being free from duplicity. The latter interpretation seems to be also suitable, especially in terms of the motif of multiplicity and the unreliable narrator.

\section{Translation of alliteration in description of appearance}

In Pnin, it is not only proper names which constitute the image of the main character. From the very beginning, when the narrator is introducing Pnin sitting in a railway coach, he depicts details of his specific, somewhat odd, physical appearance with remarkable precision. His baldness, tanned complexion, tortoise-shell glasses (masking an infantile absence of eyebrows), apish upper lip, thick neck or spindly legs make his portrait to be more caricaturelike and even clownish. Furthermore, the peculiarities of his appearance are strengthened and exaggerated by "echoing" sounds, as illustrated in Table 2.

Table 2. Appearance

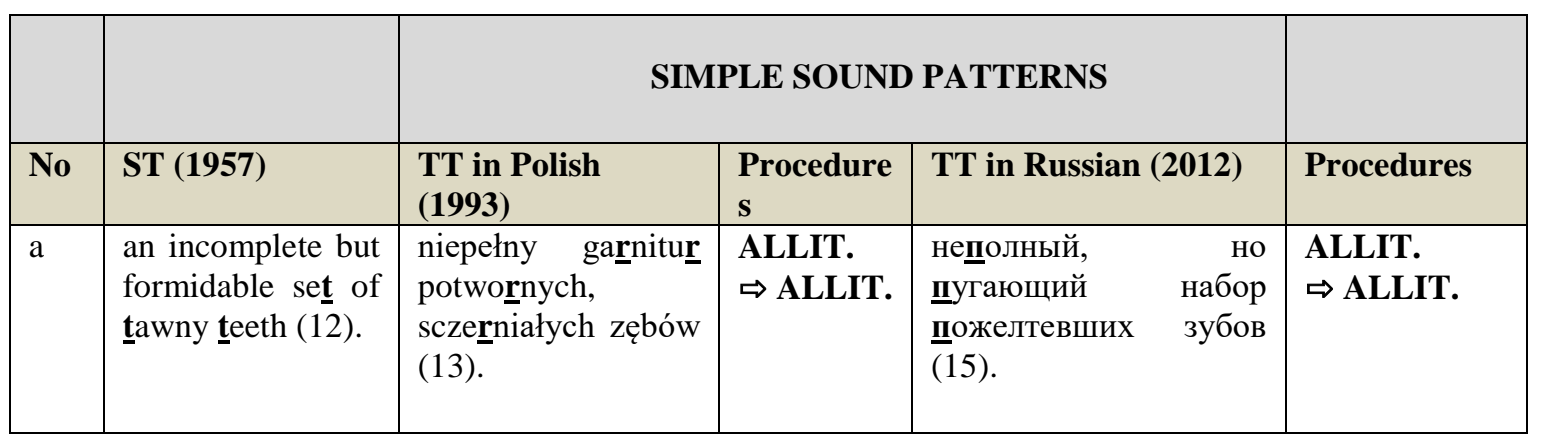




\begin{tabular}{|c|c|c|c|c|c|}
\hline & & \multicolumn{3}{|c|}{ COMPLEX SOUND PATTERNS } & \multirow[b]{2}{*}{ Procedures } \\
\hline & ST (1957) & $\begin{array}{c}\text { TT in Polish } \\
\text { (1993) }\end{array}$ & $\begin{array}{c}\text { Procedure } \\
\text { s }\end{array}$ & TT in Russian (2012) & \\
\hline $\mathrm{b}$ & $\begin{array}{l}\text { His tongue, a fat } \\
\text { sleek seal, used to } \\
\text { flop and slide so } \\
\text { happily among the } \\
\text { familiar rocks } \\
(20) \text {. }\end{array}$ & $\begin{array}{l}\text { Jego język niczym } \\
\text { thusta, lśniaca foka } \\
\text { plaskal i ślizgał się } \\
\text { po znajomych } \\
\text { skałach }(35) \text {. }\end{array}$ & $\begin{array}{l}\text { ALLIT. } \\
\Rightarrow \\
\text { SUBST. }\end{array}$ & 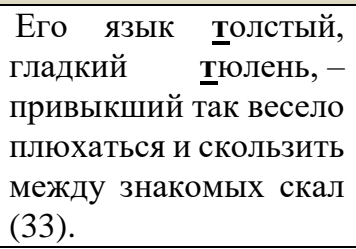 & $\begin{array}{c}\text { ALLIT. } \\
\Rightarrow \text { ALLIT. }\end{array}$ \\
\hline $\mathrm{c}$ & $\begin{array}{l}\text { strong-man torso } \\
\text { in a tightish tweed } \\
\text { coat }(5) \text {. }\end{array}$ & $\begin{array}{l}\text { a pod przyciasną } \\
\text { tweedową } \\
\text { marynarką klatka } \\
\text { piersiowa dobrze } \\
\text { zbudowanego } \\
\text { mężczyzny (7). }\end{array}$ & $\begin{aligned} \text { ALLIT. } \\
\Rightarrow \text { ALLIT. }\end{aligned}$ & $\begin{array}{l}\text { торс силача в } \\
\text { тесноватом } \\
\text { пидидовом } \\
\text { (5). }\end{array}$ & $\begin{array}{l}\text { ALLIT. } \\
\Rightarrow \text { ALLIT. }\end{array}$ \\
\hline $\mathrm{d}$ & $\begin{array}{l}\text { frail-looking, } \\
\text { almost feminine } \\
\text { feet }(5) .\end{array}$ & $\begin{array}{l}\text { drobne, niemal } \\
\text { kobiece stopy (7). }\end{array}$ & $\begin{array}{l}\text { ALLIT. } \\
\Rightarrow \text { NON- } \\
\text { ALLIT. }\end{array}$ & $\begin{array}{l}\text { с_хрупкими 푸 вид, } \\
\text { почти что женскими } \\
\text { ступнями (5). }\end{array}$ & $\begin{aligned} \text { ALLIT. } \\
\Rightarrow \text { ALLIT. }\end{aligned}$ \\
\hline $\mathrm{e}$ & $\begin{array}{l}\text { His sloppy socks } \\
\text { were of } \underline{\text { scarlet }} \\
\text { wool with lilac } \\
\text { lozenges (5). }\end{array}$ & $\begin{array}{l}\mathrm{Na} \text { nogach miał } \\
\text { opadające wełniane } \\
\text { skarpety, czerwone } \\
\text { w liliowe romby (7). }\end{array}$ & $\begin{array}{l}\text { ALLIT. } \\
\Rightarrow \text { NON- } \\
\text { ALLIT. }\end{array}$ & 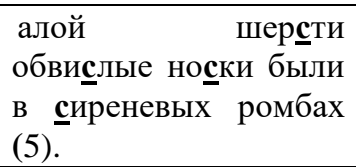 & $\begin{aligned} \text { ALLIT. } \\
\Rightarrow \text { ALLIT. }\end{aligned}$ \\
\hline $\mathrm{f}$ & $\begin{array}{l}\begin{array}{l}\text { he had always } \\
\text { long }\end{array} \\
\text { worn } \\
\text { underwear, its } \\
\text { terminals tucked } \\
\text { into the tops of } \\
\text { neat silk socks, } \\
\text { which } r \text { were } \\
\text { clocked, soberly } \\
\text { coloured, and held } \\
\text { up on his cotton- } \\
\text { clad calves by } \\
\text { garters (5). }\end{array}$ & $\begin{array}{l}\text { nosił zawsze długie } \\
\text { kalesony, których } \\
\text { ḱońce wpuszczał } \mathrm{w} \\
\text { porządne jedwabne } \\
\text { skarpetki } \\
\text { wzorkiem, } \\
\text { stonowanych } \\
\text { kolorach, } \\
\text { podtrzymywane } \\
\text { podwiązknami (7). }\end{array}$ & $\begin{aligned} & \text { ALLIT. } \\
& \Rightarrow \text { ALLIT. }\end{aligned}$ & \begin{tabular}{lr} 
он всегда & носил \\
длинные & \multicolumn{2}{c}{ кальсоны, } \\
окончанья & \multicolumn{1}{c}{ которых } \\
заправлялись & в \\
опрятные & шелковые \\
носқи & умеренной \\
расцветкй & и со \\
стрелкой, & \\
державшихся & на \\
обтянутых & бумазеей \\
икрах при & помощи \\
подвязок (5). \\
\end{tabular} & $\begin{aligned} & \text { ALLIT. } \\
& \Rightarrow \text { ALLIT. }\end{aligned}$ \\
\hline
\end{tabular}

One can notice that original passages consist of alliterative chains in which voiceless sounds: /f/, /p/, /t/, /k/ predominate over voiced consonants. Alliteration here creates a specific rhythm for the utterances. Neighbouring words seem to be akin to each other and, what is more, they establish associative connections with the referents. For instance, /f/ occurs in the word "frail" and is further repeated in "feminine" indicating the delicacy on Pnin's feet. Moreover, it also successfully imitates the sound of "flopping" made by the tongue "wandering" in Pnin's toothless mouth. The consonant /s/ in "sloppy socks" highlights the sloppiness; /t/ in "strong man torso", contrary to the feet, stresses a male-looking and rather muscular posture and at the same time indicates the characteristic tawny shade of his teeth which is distinguished in the TTs (in Polish they are black - sczerniaty; in Russian yellow - пожелтевшие).

Both translators strive to recreate sonic attributes and rhythm. They do so by superseding alliterative structures with different rhetorical devices. Frequently, consonance is 
introduced. On account of syntactical, morphological and phonological differences between English, Polish and Russian non-identical letters are duplicated (Polish version: /p/, /r/, /k/; Russian version: $/ \mathrm{p} /, / \mathrm{t} /, / \mathrm{n} /, / \mathrm{s} /, / \mathrm{k} /$ ). Thus not every consonance is the result of the translators' creativeness. Some of them are coincidental and reduced to shorter doublets or triplets. This weakens the phonetic intensity in comparison to the original and affects the character's image.

Apart from consonance, onomatopoeia is also used. This may be exemplified in the passage concerning Pnin's dental problems. Here, except for alliteration, one syllable words (fat, flop sleek, seal, slide) may pose a challenge for translators. Kołyszko uses the words lśniący ('smooth' and 'glossy'), ślizgać ('move smoothly') containing a voiceless alveolopalatal sibilant fricative /6/ and plaskać with the characteristic clusters /pl/ and /sk/. Admittedly, both terms perfectly emulate the sound accompanying the tongue movements. Ilyin not only employs the onomatopoeic equivalent плюхаться which pertains to a sound made by something striking or falling into liquid, but also keeps the repetition of initial sounds / $t /$ which may be viewed as random (олостый ['fat']; тею лень ['seal']).

In some cases the translators are not able to overcome phonetic difficulties and completely forgo not only alliteration but also a piece of information. This is best illustrated especially in the Polish version in the passage concerning the way Pnin wears underwear (2eP) where the phrase $\underline{\mathbf{c}}$ otton-c $\underline{\mathbf{c}}$ lad $\underline{\mathbf{c}}$ alves is omitted. The narrator sketches in detail Pnin's previous style and marks the chronological framework by saying "prior to 1940" and the "European era of his life". He even goes back to the $16^{\text {th }}$ century by mentioning socks with clocks pattern which were very popular at that time. Perhaps, for Kołyszko, Pnin's attachment to the oldfashioned style is so apparent that it may be deleted in the translation without any harm to his overall image. While comparing the TTs the general strategy for translating alliteration is aimed at featuring certain phonetic markers which determine the aesthetic quality of the texts. Omissions or amplifications are rather rare solutions and even if they do occur they neither diminish nor overburden the content. Target readers receive the genuine portrait of the man whose face, body parts and even clothing disclose not only his helplessness but also his mental and cultural distinctiveness.

\section{Translation of "alliterative feelings"}

Pnin's émigré experience is also ingrained in his feelings and emotions. They do not refer to this period itself but to its consequences, mainly his inability to acculturate completely. Generally, readers have the impression that he is happy in "humane" America. Only sometimes 
does an apparently happy Pnin unexpectedly break, fall apart and start crying. Semantically, his emotional states are related to pain caused by isolation. He feels sadness, despair and emptiness. Sometimes these emotional states are also accompanied by psychophysical complaints, such as: faster heartbeats, sweating and syncope. Structurally, these emotions are joined by the coordinate conjunction "and" which indicates that they are equally perceived. Casting a glance at alliterative doublets allows us to devise the translation procedures used in the TTs.

Table 3. Feelings/mood/emotions

\begin{tabular}{|c|c|c|c|c|c|}
\hline \multirow[b]{2}{*}{ No } & \multicolumn{5}{|c|}{ DOUBLETS } \\
\hline & ST (1957) & $\begin{array}{l}\text { TT in Polish } \\
\text { (1993) }\end{array}$ & Procedures & $\begin{array}{c}\text { TT in Russian } \\
(2012)\end{array}$ & Procedures \\
\hline $\mathrm{a}$ & $\begin{array}{l}\text { Pnin felt that the } \\
\text { repulsive automaton } \\
\text { he lodged had } \\
\text { developed } \\
\text { consciousness of its } \\
\text { own and not only was } \\
\text { grossly alive but was } \\
\text { causing him pain and } \\
\text { panic (14). }\end{array}$ & $\begin{array}{l}\text { Pnin stwierdził, że } \\
\text { ów automat } \\
\text { zamieszkujący jego } \\
\text { ciało, zyskał własną } \\
\text { świadomość i nie } \\
\text { tylko żyje swoim } \\
\text { życiem, lecz } \\
\text { również naraża } \\
\begin{array}{l}\text { Pnina na ból i } \\
\text { strach (15). }\end{array}\end{array}$ & $\begin{array}{l}\text { ALLIT. } \\
\Rightarrow \text { NON- } \\
\text { ALLIT. }\end{array}$ & $\begin{array}{l}\text { Пнин испытывал [...] } \\
\text { ощущение, что } \\
\text { отвратный автомат, } \\
\text { обитающий в нем, } \\
\text { обзавелся } \\
\text { собственным } \\
\text { разумом и не просто } \\
\text { живет своей } \\
\text { животной жизнью, } \\
\text { но насылает на него } \\
\underline{\text { болль и боязнь }} \\
\text { (18). }\end{array}$ & $\begin{array}{c}\text { ALLIT. } \\
\Rightarrow \text { ALLIT. }\end{array}$ \\
\hline $\mathrm{b}$ & $\begin{array}{l}\text { he set himself to } \\
\text { solve this dreary } \\
\text { riddle, but the fever } \\
\text { that hummed in his } \\
\text { head drowned every } \\
\text { effort in pain and } \\
\text { panic(17). }\end{array}$ & $\begin{array}{l}\text { Postanowił } \\
\text { rozwiązać tę } \\
\text { mroczną zagadkę, } \\
\text { ale brzęcząca w } \\
\text { głowie gorączka } \\
\text { pogrążała w bólu i } \\
\underline{\text { udręce wszystkie }} \\
\text { jego wysiłki (16). }\end{array}$ & $\begin{array}{l}\text { ALLIT. } \\
\Rightarrow \text { NON- } \\
\text { ALLIT. }\end{array}$ & 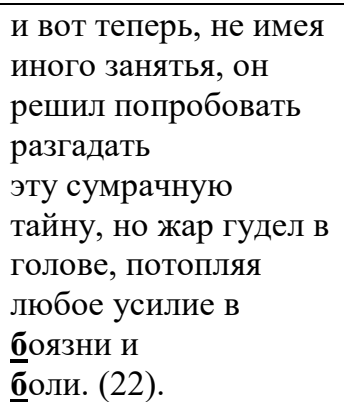 & $\begin{array}{c}\text { ALLIT. } \\
\Rightarrow \text { ALLIT. }\end{array}$ \\
\hline $\mathrm{c}$ & $\begin{array}{l}\text { He pressed his poor } \\
\text { bald head against the } \\
\text { stone back of the } \\
\text { bench and recalled all } \\
\text { the past occasions of } \\
\text { similar discomfort } \\
\text { and despair (26). }\end{array}$ & $\begin{array}{l}\text { Złożył więc biedną } \\
\text { łysą głowę na } \\
\text { kamiennym } \\
\text { oparciu ławki, żeby } \\
\text { wrócić pamięcią do } \\
\text { minionych chwil } \\
\text { podobnego } \\
\text { niepokoju } \\
\underline{\text { b} e z s i l n o s ́ c i ~(22) . ~}\end{array}$ & $\begin{array}{l}\text { ALLIT. } \\
\Rightarrow \text { NON- } \\
\text { ALLIT. }\end{array}$ & $\begin{array}{l}\text { Прижимая бедную } \\
\text { лысую } \\
\text { голову к каменной } \\
\text { спинке скамьи, он } \\
\text { вспоминал все } \\
\text { прежние приступы } \\
\text { такой же } \\
\underline{\text { немощи и отчаяния. }} \\
\text { (24). }\end{array}$ & $\begin{array}{l}\text { ALLIT. } \\
\Rightarrow \text { NON- } \\
\text { ALLIT. }\end{array}$ \\
\hline $\mathrm{d}$ & $\begin{array}{l}\text { The sensation poor } \\
\text { Pnin experienced } \\
\text { was something very } \\
\text { like that divestment, } \\
\text { that communion. He } \\
\text { felt porous and } \\
\text { pregnable (18). }\end{array}$ & $\begin{array}{l}\text { [...] doznanie } \\
\text { biednego Pnina } \\
\text { graniczyło niemal z } \\
\text { tym uwolnieniem i } \\
\text { zjednoczenie. } \\
\text { Zupełnie jakby mu } \\
\text { się otworzyły } \\
\text { wszystkie pory, } \\
\text { jakby można było }\end{array}$ & $\begin{array}{l}\text { ALLIT. } \\
\Rightarrow \text { NON- } \\
\text { ALLIT. }\end{array}$ & $\begin{array}{l}\ldots] \text { чувство, которое } \\
\text { испытывал бедный } \\
\text { Пнин, чем-то весьма } \\
\text { походило и на это } \\
\text { разоблачени, и на это } \\
\text { причащение. } \\
\text { казался Он } \\
\text { пористым, уязвимым } \\
\text { (20). }\end{array}$ & $\begin{array}{l}\text { ALLIT. } \\
\Rightarrow \text { NON- } \\
\text { ALLIT. }\end{array}$ \\
\hline
\end{tabular}




\begin{tabular}{|c|c|c|c|c|c|}
\hline & & $\begin{array}{l}\text { nim zawładnąć od } \\
\text { wewnątrz (19). }\end{array}$ & & & \\
\hline $\mathrm{e}$ & $\begin{array}{l}\text { Occasionally, when } \\
\text { puzzled by his } \\
\text { tumbling and } \\
\text { tottering pulse (18). }\end{array}$ & $\begin{array}{l}\text { Czasem lekarze, } \\
\text { zdumieni jego } \\
\text { skaczącym, } \\
\text { chwiejnym pulsem, } \\
\text { badali go staranniej } \\
(19) .\end{array}$ & $\begin{array}{l}\text { ALLIT. } \\
\Rightarrow \text { NON- } \\
\text { ALLIT. }\end{array}$ & $\begin{array}{l}\text { Время от времени } \\
\text { доктора, озадаченные } \\
\text { его шатким и валким } \\
\text { пульсом проводили } \\
\text { тщательное } \\
\text { обследование (21). }\end{array}$ & $\begin{array}{l}\text { ALLIT. } \\
\Rightarrow \text { NON- } \\
\text { ALLIT. }\end{array}$ \\
\hline $\mathrm{f}$ & $\begin{array}{l}\text { It soon transpired that } \\
\text { Timofey was a } \\
\text { veritable } \\
\text { encyclopedia of } \\
\text { Russian shrugs and } \\
\text { shakes, had tabulated } \\
\text { them, and could add } \\
\text { something to } \\
\text { Laurence's files on } \\
\text { the philosophical } \\
\text { interpretation of } \\
\text { pictorial and non- } \\
\text { pictorial, national } \\
\text { and environmental } \\
\text { gestures }(21) \text {. }\end{array}$ & $\begin{array}{l}\text { Niebawem okazało } \\
\text { się, że Timofiej jest } \\
\text { chodzącą } \\
\text { encyklopedią } \\
\text { rosyjskich odmian } \\
\text { wzruszania } \\
\text { ramionami oraz } \\
\text { kiwania głową } \\
(38) .\end{array}$ & $\begin{array}{l}\text { ALLIT. } \\
\Rightarrow \text { NON- } \\
\text { ALLIT. }\end{array}$ & 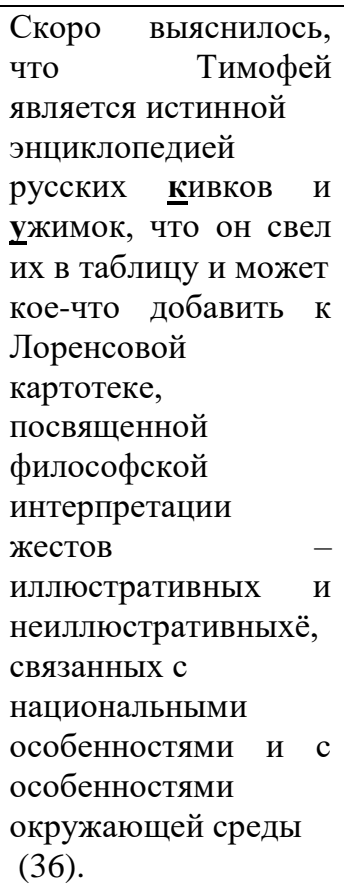 & $\begin{array}{l}\text { ALLIT. } \\
\Rightarrow \text { NON- } \\
\text { ALLIT. }\end{array}$ \\
\hline
\end{tabular}

Strikingly, in those examples the phrase "pain and panic" appears twice. Besides its general sense, it is used in different situational contexts. The first refers to the aforementioned event when Pnin misses the train to Cremona, the second one is connected with recollections of his disease when he was a child. In those episodes the same feelings and thoughts beset Pnin. On the one hand, pain intensified by panic delineates his overall psychic condition; on the other hand, together they accent his vulnerability to exaggerated reactions to external situations.

On the phonetic level the Russian translation in a sense patterns the original (боль ('pain') and боязнь ('panic') appear); it preserves the alliterative form and the quality of initial consonants (it contains the voiced consonant /b/ - a pair of voiceless /p/). With respect to the general meaning, it is slightly changed because semantically боязнь ('fear') seems to be not so strong and sudden as panic. Nonetheless, Ilyin consistently uses these equivalents whereas Kołyszko proposes two solutions for translating the second component: ból i strach ('fear') and ból i udręka ('torment'). Noticeable references to dissimilar sensations probably are conditioned by the translator's interpretation of the fragments in which these words appear. 
She endeavours to recreate the situational context as faithfully as possible and chooses words which match better. By doing so she again destroys alliterative doublets. Apparently she is opting for denotative rather than formal-aesthetic equivalence.

In this thematic group translators in most cases forgo alliterative chains. In contrast to previous thematic fields, considerable inaccuracies in the meaning of emotions may be observed. For instance discomfort (3c) is substituted by anxiety (niepokój) 'an uncomfortable feeling of nervousness or worry' (Polish version) and malaise (немощь) 'a general feeling of being ill or having no energy' in the Russian version. In the Polish text despair is converted to bezsilność 'helplessness' - (the feeling or state of being unable to do anything to help oneself or anyone else), whereas in the Russian text it is used in its original sense. Words which replace general concepts usually refer to negative feelings and, in comparison to the original, create a poorer and more miserable psychic condition for Pnin. Pnin's heartbeats are described in a very vivid way (3d) as a confirmation of his extraordinary agitation. Kołyszko uses dictionary equivalents, ignoring phonetic and onomatopoeic values. Ilyin uses a counterpart which in the Russian language is a proverb и шатко, и валко, и на сторону and means to live or do something very badly. Apparently, Russian readers immediately recognize and understand this saying. When one compares it with the original text it is clear that the target readers receive a fully compatible message even if it is expressed by different linguistic means.

In sketching emotions and feelings Nabokov repeatedly resorts to astonishing juxtapositions; therefore, they often seem to be senseless and difficult to define precisely. Because of this, the translators are forced to rely on their sensitivity and cleverness to retain logical connections with the original and make the TTs more readable ( $3 \mathrm{~d}$ and $3 \mathrm{f}$ ). The first one contains the phrase "porous and pregnable" preceded by "divestment and communion". As regards sensations, the phrase loses its clarity. In Russian Ilyin does not face the problem of finding one-word equivalents as Kołyszko does. He introduces words which preserve the original idea, although he does so at the cost of alliteration. The translators' struggle to recreate sensations is shown in the Polish version where Kołyszko clarifies the content and broadens the utterance by including additional information. It seems that her choice to render the passage by means of paraphrase and simile is justified even if they describe sensations rather than naming them. Although in Polish there are dictionary equivalents porowaty or nieszczelny they are not usually used with respect to mental/psychic states. In order to give the Polish audience some insight into the character's emotions, the translator makes it more approachable for them. At the same time, by using other rhetorical devices, she compensates for the loss of alliteration. 
A similar situation occurs when Pnin is metaphorically called an "encyclopedia of Russian shrugs and shakes". In Ilyin's version “shrugs and shakes" are substituted by кивки ('nods of the head') and ужимки ('grimace'), which both relate to the semantic field HEAD. In the Polish translation, on account of the lack of a one-word substitute, it is more challenging. Kołyszko does not change her strategy and persistently amplifies the text by specifying the parts of bodies performing certain gestures. It must be stressed that this element of non-verbal communication becomes the object of special interest of Laurence Clements. During his conversation with Pnin the character demonstrates the movements referred to in the phrases махнуть рукой ('to give up'), всплеснуть руками ('to clasp one's hands'), развести руками ('to be at a loss'), which emphasizes the relationship between the language, emotions and physical behaviour. In this way Nabokov shows how deeply culture affects Pnin as a man and gives him a sense of "Russianness".

\section{Conclusion}

Culture clash, allusions to Russian emigration, the figure of the main character, and an unreliable storyteller make Nabokov's book still amenable to new elucidations. The narrator's language is especially interesting material for the analysis on account of its phonetic features created by numerous alliterations. In Russian and Polish translations this property can be lost but this does not violate either the plot or the general purport of the masterpiece. Translation procedures in Pnin correspond with those Kujawska-Lis distinguishes. The most frequent, especially when it comes to proper names and feelings, is the introduction of non-alliterative words and phrases. Although they are translated literally into Polish and Russian, two instances of applying descriptive equivalents (the Polish translation of "shrugs and shakes" and "porous and pregnable") are visible. It must be noted that such a change does not overbalance the quantitative relation between the ST and the TT. Examples of replacement may also be found in the translations. Here, consonances and onomatopoeia function as substitutes. They occur mostly in the passages describing Pnin's appearance and to some extent follow the original and imply the rhythm of the utterances. When comparing the selected translations of Pnin, it becomes evident that the translators are torn between attempts to achieve formal-aesthetic and denotative equivalence. Overall, even if they do not preserve the alliterative effect, the applied solutions allow them to keep the aesthetic value. When it comes to re-painting the image of the main character in the translations, some inaccuracies may be observed. This mainly refers to 
the examples describing Pnin's feelings and emotions in which in most cases alliterative word strings are omitted and semantically distant counterparts are used.

\section{References}

Barańczak, Stanisław (2004) Ocalone $w$ thumaczeniu: szkice o warsztacie tlumacza poezji z dodatkiem Małej antologii przekładów-problemów. Kraków: Wydawnictwo “a5”.

Bodenstein, Jurgen (1977) The Excitement of Verbal Adventure. A Study of Vladimir Nabokov's Prose. Heidelberg: Ripol Classic Publishing House.

Cronan, David (1986) “Alliterative Rank in Old English Poetry.” Studia Neophilologica 58(2); $145-158$.

Goldsmith, Ulrich K. (1950) "Words out of the Hat? Alliteration and Assonance in Shakespeare's Sonnets.” The Journal of English and Germanic Philology 49(1); 33-48.

Halmari, Helena (2011) "Inaugural Addresses from George Washington to Barack Obama." [In:] Jonathan Roper (ed.) Alliteration in Culture. London: Palgrave Macmillan; 45-61.

Harte, Jeremy (2011) "Love, Silver and the Devil: Alliteration in English Place-Names." [In:] Jonathan Roper (ed.) Alliteration in Culture. London: Palgrave Macmillan; 21-33.

Hoover, David L. (1985) "Evidence for Primacy of Alliteration in Old English Metre.” AngloSaxon England, 14; 75-96.

Kujawska-Lis, Ewa (2007) “Aliteracje zagubione w tłumaczeniu. Analiza porównawcza trzech tłumaczeń opowiadania G. K. Chestertona The Strange Crime of John Boulnois.” Prace Językoznawcze, 9(1); 65-80.

Kujawska-Lis, Ewa (2018) "Alliteration as a Means to Reinforce Orality in Conrad's Early Marlow's Narratives." Zagadnienia Rodzajów Literackich, 61(1); 85-99.

Lokrantz, Jessie Thomas (1973) The Underside of the Weave: Some Stylistic Devices Used by Vladimir Nabokov. Uppsala. Doctoral dissertation at Uppsala University.

Lea, R. Brooke, David N. Rapp, Andrew Elfenbein, Aaron D. Mitchell, Russell Swinburne Romine (2008) "Sweet Silent Thought: Alliteration and Resonance in Poetry Comprehension." Psychological Science 19(7); 709-716.

Lewis, Richard A. (1975) "Plurilinear Alliteration in Old English Poetry." Texas Studies in Literature and Language 16(4); 598-602.

Lotman, Mihhail; Maria-Kristiina Lotman, (2015) "Lost and Found in Translation: a Case of Alliteration." Studia Metrica et Poetica 2.1, 34-57. 
Mucha, Bogusław (1989) Historia literatury rosyjskiej. Zarys. Wrocław-Warszawa-Kraków: Zakład Narodowy im. Ossolińskich.

Nabokov, Vladimir (1957) Pnin. New York: Vintage Books.

Nabokov, Vladimir ([1957]1993) Pnin. [Translated by Anna Kołyszko]. Warsaw: DaCapo.

Nabokov, Vladimir ([1957]2012) Pnin. [Translated by Sergey Ilyin]. Moscow: Simpozium.

Rampton, David (2012) Vladimir Nabokov. A Literary Life. Palgrave: Macmillian.

Roper, Jonathan (2012) "Synonymy and Rank in Alliterative Poetry." Sign Systems Studies 40(1/2); 82-93.

Roper, Jonathan (2014) “Alliteration Lost, Keep and Gained: Translation as an Indicator of Language-Specific Prosaics.” [In:] Anneli Baran, Liisi Laineste, Piret Voolaid (eds.) Scala Naturae. Festshrift in Honour of Arvo Krikmann.Tartu: ELM Sholarly Press; 419-435.

Sarv, Mari (1999) "Regilaur: Clearing the Alliterative Haze." The Electronic Journal of Folklore 10; 127-140.

Smith, Karen (2006) "Rhetorical Figures and the Translation of Advertising Headlines." Language and Literature 15(2); 159-182.

Stewart, Dabney (1977) “Nabokov's Pnin: floating and singing.” [In:] Harry R. Garbin (ed.) Makers of the twentieth century novels. Lewisburg: Bucknell University Press; 259-275.

Terasawa, Jun (2011) Old English Metre. An Introduction. Toronto, Buffalo, London: University of Toronto Press.

Williams, Fionnuala Carson (2011) "Alliteration in English-Language Versions of Current Widespread European Idioms and Proverbs." [In:] Jonathan Roper (ed.) Alliteration in Culture. London: Palgrave Macmillan; 34-44.

Wimsatt, James I. (1998) “Alliteration and Hopkin's Sprung Rhythm.” Poetics Today 19(4); $531-564$.

\section{Internet resources}

Barabtarlo, Gennady (1993) A Resolved Discord (Pnin). Retrieved from: https://www.libraries.psu.edu/nabokov/barab21.htm. Accessed 20 December 2018.

Blackwell, Stephen. The History of The Nabokovian. Retrieved from: https://thenabokovian.org/about/. Accessed 15 May 2019.

Mayakovsky, Vladimir (1918) Хорошее отношение $\kappa$ лошадям. Retrieved from: https://ilibrary.ru/text/1237/p.1/index.html. Accessed 28 February 2019. 
Mayakovsky, Vladimir (2013) The Good Treatment for Horses. Translated by Tamara Vardomskaya. Retrieved from: https://vardomskaya.com/2016/07/26/the-goodtreatment-of-horses-v-mayakovsky. Accessed 28 February 2019.

The Cambridge Online Dictionary. Retrieved from: https://dictionary.cambridge.org/. Accessed 21 February 2019.. 